\title{
The analysis of truncated vocatives in Taviano (Salentino) Italian*
}

\author{
Michael Kenstowicz \\ Massachusetts Institute of Technology \\ kenstow@mit.edu
}

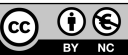

Received: December 30, 2018

Accepted: June 5, 2019

\begin{abstract}
This paper documents and discusses various descriptive generalizations and alternative analyses of the vocative truncation found in the Southern Italian dialect of Taviano that is illustrated by such formations as Filoména > Filomé. We show that the upper limit on the size of the truncate is not restricted by foot binarity nor by internally layered feet: Addoloráta $>$ Addolorá. The lower limit of the truncate may extend to a single CV syllable in violation of foot binarity: Césare $>C e ́$. But truncation to just the stressed vowel is rejected: Élena $>{ }^{*} E$. We situate the analysis of the vocative truncation within the overall grammar of Salentino and show that while some properties such as the loss of coda consonants can be attributed to rankings imposed by the surrounding grammar, others are peculiar to this construction. The analysis of stress in loanword adaptation figures prominently in our discussion. The final sections examine some of the morphological and syntactic properties of the Taviano vocative.
\end{abstract}

Keywords: vocative; truncation; loanword adaptation; stress

Resum. L'anàlisi dels vocatius truncats en tavià (salenti)

Aquest article documenta i discuteix diverses generalitzacions descriptives i anàlisis alternatives del truncament vocatiu en tavià, un dialecte del sud d'Itàlia, que es pot il·lustrar amb exemples com Filoména $>$ Filomé. Es demostra que el límit superior en relació a la mida màxima del truncat no es restringeix al peu binari ni als peus mínimament recursius: Addoloráta $>$ Addolorá. El límit inferior del truncat pot arribar a una sola síl·laba CV, amb violació del requisit de binarietat: Césare $>C e ́$, tot i que es rebutja el truncament quan el resultat és una vocal tònica: Élena $>* E$. L'anàlisi del truncament vocatiu se situa en el context de la gramàtica general del salentí i demostra que, mentre algunes propietats com la pèrdua de consonants en posició de coda es poden atribuir als rànquings imposats per la gramàtica del salentí, altres són específiques d'aquesta construcció. L'anàlisi de l'accent en l'adaptació de manlleus constitueix un aspecte prominent de la proposta. La secció final examina algunes de les propietats morfològiques i sintàctiques del vocatiu del tavià.

Paraules clau: vocatiu; truncament; adaptació de manlleus; accent; Salentino

* Thanks to Stanislao Zompi for sharing his language and for his many contributions to the analyses and discussions in this paper. Any remaining errors are the responsibility of the author. We also thank our two anonymous CJL reviewers for their comments. This paper is dedicated to Guglielmo Cinque in recognition of his vital role in nurturing the development of generative grammar in Italy as well as for his research in typology and emarginazione. 


\section{Table of Contents}

\section{Introduction \\ 2. Truncated Vocatives \\ 3. Background}

4. Vocatives and truncated vocatives

5. Prior analyses-1 (Alber 2009)

6. Prior-Analyses-2

(Vanrell \& Cabré 2011; Cabré \& Vanrell 2016; Cabré et al. 2019)
7. Prior-Analyses-3

(D’Alessandro \& van Oostendorp 2016)

8. Summary of Phonological

Characteristics of the Vocative

9. Morphological and Grammatical

Properties of the Taviano Vocative

10. Summary and conclusion

References

Appendix

Omaggio a G. Cinque

\section{Introduction}

The canonical morphological operation is affixation to a base. Truncation processes seen in hypocoristic formations such as Michael $>$ Mike are anomalous from this perspective - in two senses. First, there is no affix. Second, the output is shorter/ smaller than the base. Such truncation processes are typically divided into several subtypes. A major division is between subtractive morphology vs. prosodically targeted compressions. In the former, the change to the base is minimal and in the best-studied cases involves filling a slot in an inflectional paradigm, as in Kosati plurals (Kurisu 2001) and Icelandic deverbal nouns (Oreshnik 1972; Kiparsky 1984). Prosodically-motivated truncation comprises clippings, hypocoristics, and vocatives. The first two types usually involve mapping the base to a prosodic category such as the foot and minimal word (McCarthy \& Prince 1986). Japanese formations like demonsutoréesyon 'demonstration' > [démo] and Masako > [mása] (Ito 1990) illustrate. The two types of nickname formation first analyzed in these terms for Spanish by Prieto (1992) and for Italian by Thornton (1996) illustrate prosodic truncations in Romance (1). We use 'right vs. left edge' to refer to the site of the truncation. Their inverses are often used to denote the point of alignment of the base word with the truncating template.

\begin{tabular}{|l|l|l|l|l|l|}
\hline Spanish & \multicolumn{2}{|c|}{ right edge } & \multicolumn{2}{c|}{ left edge } \\
\hline & base & truncate & & base & truncate \\
\hline & José & Jóse & & Robérto & Béto \\
\hline & Terésa & Tére & & Alfónso & Póncho \\
\hline & Gertrúdis & Gértu & & Ernésto & Néto \\
\hline & Francísco & Fráncis & & Fernándo & Nándo \\
\hline & Margaríta & Márga & & Rosíta & Chíta \\
\hline
\end{tabular}




\begin{tabular}{|l|l|l|l|l|l|}
\hline Italian & \multicolumn{2}{|c|}{ right edge } & & \multicolumn{2}{c|}{ left edge } \\
\hline & base & truncate & & base & truncate \\
\hline & Francésca & Fránce & & Salvatóre & Tóre \\
\hline & Alessándra & Ále & & Filoména & Mćna \\
\hline & Simóna & Símo & & António & Tóto \\
\hline & Cecília & Céci & & Guglićlmo & Mćmo \\
\hline & Robérto & Róbe & & Giuséppe & Ṕ́ppe \\
\hline
\end{tabular}

Subsequently, Felíu (2001) called attention to Spanish trisyllabic truncates such as analfabéto $>$ [análfa] 'illiterate' and more recently Martínez-Paricio \& TorresTamarit (2018) document hypocoristic formations like Estanisláo > [estánis], which they analyze with minimally recursive, internally layered trochaic feet: (es(tánis)).

\section{Truncated Vocatives}

Recent literature has isolated a distinct type of truncation, which at least canonically is said to be associated with appellative (vocative) formations. This type has been detected in at least three distinct Mediterranean locales: Southern Italian, Sardinian, and Algherese Catalan. It has also been reported for certain Romanian dialects for kinship terms and personal names as well as certain morphologically defined imperative verb forms. Unlike hypocoristics and clippings, this formation does not have a fixed size but rather varies its length as a function of the location of stress and the number of pretonic syllables in the base. Examples from all four of these Romance varieties appear in (2).

(2) a. Southern Italian (Alber \& Arndt-Lappe 2012)

base vocative

Bárbara Bá

Carméla Carmé

Salvatóre Salvató

Antonélla Antoné

b. Sardinian (Cabré \& Vanrell 2016; Cabré et al. 2019)

base vocative

Bértulu

Bé

Gósamu Gó

Simóne Simó

Fortunádu Fortuná

Servatóre Servató

c. Algherese Catalan (Cabré \& Vanrell 2011)

base vocative

Fábio

Fá

Francésco Francé

Antóni Antó

Nicolétto Nicolé

Elisabéta Elisabé 
d. Maramureş Romanian (Maiden 2006)

$\begin{array}{ll}\text { base } & \text { vocative } \\ \text { nevástă } & \text { nevá } \\ \text { nepoátă } & \text { nepoá } \\ \text { tátă } & \text { tá } \\ \text { Aléxa } & \text { Alé } \\ \text { Părásca } & \text { Părá }\end{array}$

The descriptive generalization underlying the formation of such structures is that the truncate aligns with the left edge of the given-name base form and with its stressed vowel. Since the base is of potentially unbounded length, the truncate will vary its size stretching from one up to four or more syllables, the latter putting beyond the reach of an internally layered foot, as in Algherese Catalan Elisabéta $>$ [elisabé].

Our goal in this paper is to document and analyze this truncation process in more detail based on data from the Italian dialect of Taviano (Salentino). But first we situate the vocative construction in the overall grammar of this dialect.

\section{Background}

Taviano has many of the features common to Southern Italian dialects in general. It has five vowels in stressed position and lacks the open-close mid vowel distinction of Tuscan-based Standard Italian. The mid vowels /o/ and /e/ generally are barred from postonic position except that the latter may appear word-finally. In pretonic position vowel reduction occurs in the oldest layer of the vocabulary and is reflected in paradigmatic alternations found in the inflection of verbs. Here unstressed $/ 0 /$ is realized as $[\mathrm{u}]$ while unstressed /e/ is realized as [a] - the latter in contradistinction to most other Salentino varieties, where it surfaces as [i]: [véne] 3sG, [vanímu] 1PL 'come' and [móre] 3SG, [murímu] 1PL 'die'. The dialect has eliminated the metaphony found in other Salentino locales (most notably Lecce, Calabrese 1984) and retains remnants in just a handful of items such as [fjérru] 'iron', [jéntu] 'wind', [jérnu] 'winter' (cf. St. Italian ferro, vento, (in)verno). Diphthongs of both rising [je] and falling [aun] sonority occur as well as geminate consonants, with /b/, /dz/, and $/ \mathrm{n} /$ always geminated intervocalically, and $/ \mathrm{dd} /$ often realized as a retroflex. The Taviano syllable template is CCVC with codas restricted to /s/, liquids, and nasals homorganic with the following onset consonant. In word-final position codas are largely absent. The latter restriction is actively enforced since loanwords ending in a consonant are regularly repaired by copy-vowel epenthesis.

(3) St. Italian Taviano

$\begin{array}{lll}\text { film } & \text { fílmi } & \text { 'film' } \\ \text { bar } & \text { bárra } & \text { 'bar, café' } \\ \text { Úpim } & \text { Úpimmi } & \text { brand name } \\ \text { Cónad } & \text { Kónadda } & \text { brand name }\end{array}$


There is also a word-minimality requirement in Taviano so that many monosyllables of Standard Italian appear with a lexically determined augment composed of a coronal consonant plus /e/. Examples appear in (4). ${ }^{1}$

(4) St. Italian Taviano

$\begin{array}{lll}\text { no } & \text { nóne } & \text { 'no' } \\ \text { sì } & \text { síne } & \text { 'yes' } \\ \text { va } & \text { váje } & \text { 'go' 3sg } \\ \text { chi } & \text { tfíte, tfine } & \text { 'who' } \\ \text { tre } & \text { tréte } & \text { 'three' }\end{array}$

As far as clippings and hypocoristic formations are concerned, Taviano has the left-edge truncation structure targeting a disyllabic trochaic template that is found in many other varieties of Italian and Romance more generally (cf. 1). The nicknames display segmental and prosodic TETU effects in which a consonant is inserted or copied that are comparable to those observed in Standard Italian, Spanish (BoydBowman 1955; Piñeros 2000), and English.

\begin{tabular}{|l|l|l|l|}
\hline \multicolumn{2}{|c|}{ St. Italian } & \multicolumn{2}{c|}{ Taviano } \\
\hline base & nickname & base & nickname \\
\hline Alessándro & Sándro & Lisándru & Sándru \\
\hline Salvatóre & Tóto & Salvatóre & Tótu \\
\hline Luígi & Gígi & Luvít ji, Luvíddzi & T Jítfi, Pítfi \\
\hline Antoniétta & & Ntunjétta & Étta, Tétta \\
\hline Doménico & Méni, Ménico & Duméniku & Mímmu \\
\hline
\end{tabular}

But Taviano lacks the right-edge truncation noted above in (1) for Spanish and Standard Italian. On the other hand, there is another, less common pattern of data in which the stressed syllable is reduplicated with a CV prefix (6). As observed by an anonymous referee, such iambically stressed structures are common in French (e.g. Monique > Momo, Louis > Loulou). But in this case it is the initial syllable that is reduplicated, not the stressed syllable.

1. When cliticised, these elements retain their original monosyllabic form:
(i ) Kwarketùnu me someone 1sG.CLIT disse sta kosa, ma nu+ sta + me said.3SG. this thing but not PROG 1SG.CLIT remember.1SG who fose was.3sG
'Someone told me this thing, but I can't recall who it was.' 
(6) base

nickname

Kósimu Kokó

Pantaléu Lelé

Rosáriu Sasá

Salvatóre Totó

Euddzénju Dzeddzé

\subsection{Loanwords: gemination, epenthesis, and stress}

As indicated in the preceding section, words in the Taviano dialect must terminate in a vowel. Loanwords from Standard Italian as well as other languages that end in a consonant are adapted by epenthesizing a vowel in order to bring the word into conformity with this phonotactic restriction. Unlike in Tuscan Italian where the epenthetic vowel is [e], in Taviano the epenthetic vowel is a copy of the preceding syllable - at least in the adaptation of final consonants. (See Repetti 2011 for general discussion of epenthesis in Italian loanword adaptation). In addition, Taviano displays faithfulness to the source word in at least two respects that in combination create structures that deviate rather remarkably from native words. First, the final consonant of the loan is geminated (7). This kind of gemination is found in the adaptation of loanwords into Japanese, Arabic, and Hungarian-languages that like Italian have a geminate-singleton contrast. Two principal hypotheses have been offered as motivation for such gemination. One sees it as a strategy to satisfy a bimoraic condition on stressed syllables - in the Italian case in the face of a ban on word-final long vowels (Chierchia 1986; Repetti 1993). An alternative views the gemination as a faithfulness effect that allows the consonant in the loan to maintain its "syllabic role" as a coda in the donor language while also providing an onset to the following vowel. See Shinohara (1997) and Ito \& Mester (to appear) for analyses along these lines for Japanese and Bafile (2003) for Italian.

$\begin{array}{lll}\text { (7) St. Italian } & \text { Taviano } & \\ \text { bar } & \text { bárra } & \text { 'bar, café' } \\ \text { hotél } & \text { otélle } & \text { 'hotel' } \\ \text { tram } & \text { trámma } & \text { 'streetcar' } \\ \text { clan } & \text { klánna } & \text { 'clan' }\end{array}$

The Taviano data in (8) provide support for the second interpretation. These loans maintain faithfulness to stress as well as preservation of the coda status of the geminated consonant. As a result, they create words with antepenultimate stress whose penultimate syllable is closed and hence heavy-a prosodic structure that otherwise is highly anomalous and which is regularly stressed on the penult in the native vocabulary: sorélle (*sórelle) 'sisters'. The fact that the penultimate syllable is unstressed in the loan (and in its correspondent in the donor language) challenges the weight-to-stress interpretation of the loanword gemination. Bafile (2003) makes the same observation for loans in the Florentine dialect (see below). 
(8)

$\begin{array}{lll}\begin{array}{lll}\text { St. Italian } \\ \text { túnnel }\end{array} & \begin{array}{l}\text { Taviano } \\ \text { túnnelle }\end{array} & \text { 'tunnel' } \\ \text { ténnis } & \text { ténnissi } & \text { 'tennis' } \\ \text { vírus } & \text { vírussu } & \text { 'virus' } \\ \text { álbum } & \text { álbummu } & \text { 'album' } \\ \text { Fíat } & \text { Fíatta } & \text { brand name } \\ \text { Úpim } & \text { Úpimmi } & \text { brand name } \\ \text { Cómit } & \text { Kómitti } & \text { 'Comit' } \\ \text { Séat } & \text { Séatta } & \text { brand name } \\ \text { ánanas } & \text { ?ánanassa } & \text { 'pineapple' }\end{array}$

As shown by the relatively acceptable adaptation ?ánanassa 'pineapple,' faithfulness to stress can even give rise to words in which the ictus falls outside the three-syllable window that otherwise governs the locus of accent in Italian and Romance languages more generally.

In order to test whether or not the singleton vs. geminate contrast is maintained in the geminated loanwords with antepenultimate stress such as Úpimmi, we recorded a small sample of Taviano words and measured the duration of their segments. (See Appendix for the corpus). The words were spoken in isolation by our speaker and then in a sentential frame: [tokka+ditfi X kjanu kjanu] 'it is necessary to say X slowly, slowly'. First, to establish a baseline we measured the ratio of the duration of the medial consonant spanning the last two syllables with respect to the duration of the preceding stressed vowel. As in Standard Italian, Taviano stressed vowels in penultimate open syllables are lengthened relative to their duration in closed syllables. For these cases such as Michéle vs. sorélle we found that in the former the average duration ratio of the consonant relative to the preceding stressed vowel was $0.66 \mathrm{~ms}$ ( $\mathrm{st} \mathrm{dev}=0.26 \mathrm{~ms}$ ) while for the geminate it was $1.67 \mathrm{~ms}(0.40)$. A paired two-sample T-test found the difference to be highly significant $(\mathrm{p}<0.001)$. For the case of loans with the geminated consonant but antepenultimate stress such as Úpimmi vs. native singletons such as últimi there was still a significant difference in the ratio of the medial consonant spanning the last two syllables vis a vis the penultimate vowel: geminates had a ratio of $1.86 \mathrm{~ms}(0.51 \mathrm{~ms})$ vs. singletons' $1.10 \mathrm{~ms}(0.31 \mathrm{~ms})$. The ratios are different in this case because the penultimate vowel is not stressed and hence is not lengthened. Nevertheless, there is still a difference in the duration ratios of the medial consonant relative to the preceding unstressed vowel with the geminate ratio being significantly larger by a paired T-test $(\mathrm{p}<0.001)$. From these (admittedly minimal) data we conclude that the final consonants in loan adaptations such as Úpim > Úpimmi really are geminated. We also compared these ratios across the two conditions with unpaired T-tests. The ratios of the penultimate vowels in the singleton context (Michéle vs. últimi) were significantly different $(\mathrm{p}<0.001)$ while they were not in the geminate context of Upimmi vs. sorélle. It appears that the presence of a geminate cancels the vowel lengthening effect of penultimate stress.

Our Praat script also returned the F0 values for the syllables in the words composing our corpus. We focus on words embedded in the frame sentence context 
since the isolation forms seemed to be distorted by a boundary tone. For words like Úpimmi and últimi there was a slightly falling F0 contour of mean $-2.7 \mathrm{~Hz}$ (st dev $=5.5$ ) between the stressed antepenultimate syllable and the following unstressed penult. But for penultimate stressed words such as otélle and Michéle there was a sharp rise in pitch between the antepenult and the penult (mean $=23 \mathrm{~Hz}$, st dev $=$ $8.7 \mathrm{~Hz}$ ). Given that $\mathrm{H}^{*}$ pitch accents are aligned with stressed syllables in Taviano, these data support the contention that the stress falls earlier in the word in loans with a geminate consonant such as Úpimmi and show the surprising strength of faithfulness to stress in the loanword adaptation process. ${ }^{2}$

The loans with the copy vowel also stand out morphologically since they systematically fall into the class of indeclinables. So even though bárra 'bar, café' terminates in a vowel that is homophonous with the singular (typically feminine) desinence, it fails to change in the plural unlike the nativized bárra 'iron bar', which does inflect: bárre $(\mathrm{pl})$.

Another point worthy of mention is that while copy-vowel epenthesis is readily applied to the vowels $[i, \mathrm{u}, \mathrm{e}, \mathrm{a}]$ as seen in the data in (8) and (9), there is more uncertainty for the vowel [o], as seen in (10). The reason presumably is a conflict between the requirement of identity between the two vowels in the copy relation on the one hand and the otherwise general absence of [o] at the end of masculine singular nouns on the other hand. In this morphological context round vowels are regularly realized as $[\mathrm{u}]$. The latter phonotactic generalization overrides the otherwise strong segmental faithfulness found in Taviano loanwords so that Légo and Ninténdo are adapted as Légu $\left({ }^{*}\right.$ Légo $)$ and Ninténdu $(*$ Nintendo).

(10)

St. Italian
álcol, álcole
nćon
ípsilon, ipsilónne
cáos, caósse

\author{
Taviano \\ *álkollu, ?álkullu \\ *néonnu, ?'néunnu \\ *ípsilonnu \\ *káossu, ?káussu
}

\subsection{OT analysis}

The distribution of stress in native Taviano words largely aligns with Standard Italian. There is one stress per phonological word. It is located in a three-syllable window at the right edge of the word. If the penultimate syllable is closed, stress regularly falls on the penult (barring well-known, isolated exceptions such as Táranto and mándorla 'almond'). Stress location varies lexically between antepenultimate (Césare) and penultimate (Michéle) syllables, with a statistical bias in favor of the latter. Final stress is rare outside monosyllables. For purposes of discussion, we will assume a foot-free analysis that is embodied in the following constraints.

2. The sensitivity of stress in Italian to the morphological and lexical contexts in which it is located has been demonstrated by Burani et al. (2014) in a study of the accent assigned to nonce items in a reading aloud task. 
(11) OT stress constraints

CulminAtivity: penalize a word with more than one stress as well as a word with no stress

*EXTENDED-LAPSE-Right (*ELR): penalize a sequence of three unstressed syllables at the right edge of the word

ALIGN-STRESS-LEFT (AL-STR-L): assign a violation mark for each unstressed syllable that intervenes between the stressed syllable and the left edge of the word

*LAPSE-Right (*LR): penalize a word with two unstressed syllables at the right edge

NON-FInALITY (NON-FIN): penalize a word with stress on the final syllable

WEIGHT-TO-STRESS (W-TO-S): penalize an unstressed heavy syllable

The rankings among these constraints that are required to account for the generalizations governing the distribution of stress noted above can be inferred from the following violation tableau for a schematic four-syllable word that contains no heavy syllable.

\begin{tabular}{|l||l|l|l|l|}
\hline /sSSS/ & $*$ ELR & AL-ST-L & $*$ LAPSE-RT & NON-FIN \\
\hline \hline ŚSSS & $*$ & & $*$ & \\
\hline SŚsS & & $*$ & $*$ & \\
\hline SSŚs & & $* *$ & & \\
\hline SSSŚ & & $* * *$ & & $*$ \\
\hline
\end{tabular}

Undominated *EXTENDED-LAPSE-RIGHT prevents stress from moving to the left past the antepenult. The choice between antepenultimate and penultimate stress is controlled by lexically determined rankings between ALIGN-STRESS-LEFT and *LAPSE-Right: Align-Stress-Left » *LAPSE-Right favors stress on the third-last syllable (e.g. Césare) while *LAPSE-Right » ALIGN-STRESS-LefT chooses penultimate stress (e.g. Michéle). Finally, for words with a closed penultimate syllable the systematic absence of antepenultimate stress follows from ranking WEIGHT-TOStress over Align-Stress-Left.

Weight-TO-Stress » Align-Stress-LeFt
\begin{tabular}{|l||l|l|}
\hline /Roberto/ & WeIGHT-TO-STRESS & Align-Stress-LeFT \\
\hline$>$ Ro.bér.to & & $*$ \\
\hline Ró.ber.to & $* !$ & \\
\hline
\end{tabular}

With these rankings in place we can turn to the analysis of the Taviano loanwords. The native-grammar constraint against word-final consonants is enforced by truncation in vocatives but by epenthesis in loanwords. A similar discrepancy is found in other languages such as Korean (Kenstowicz 2005) where illegal conso- 
nant clusters are repaired by deletion in the native vocabulary but by epenthesis in loans. For Taviano, this implies the demotion of different faithfulness constraints with respect to ${ }^{*} \mathrm{C} \#$, as seen in the tableaux below in (14) for vocative Loréntsu $>$ Loré and loanword Úpim > Úpimmi.

(14) Final-Consonant (*C\#): penalize a word-final consonant MAX-C: penalize deletion of a consonant DEP-V: penalize insertion of a vowel

\begin{tabular}{|l||l:l|l|}
\multicolumn{1}{|c}{$*$ C\#, DEP-V » MAX-C } \\
\hline /Loréntsu/ & $*$ C\# & DEP-V & MAX-C \\
\hline \hline$>$ Loré & & & $*$ \\
\hline Lorén & $* !$ & & \\
\hline Lorén(n)e & & $* !$ & \\
\hline
\end{tabular}

\begin{tabular}{|l||l:l|l|}
\multicolumn{1}{c}{$*$ C\#, MAX-C » DEP-V } \\
\hline /Úpim/ & $*$ C\# & MAX-C & DEP-V \\
\hline \hline > Úpimmi & & & $*$ \\
\hline \hline Úpim & $* !$ & & \\
\hline Úpi & & $* !$ & \\
\hline
\end{tabular}

As indicated above, a common strategy to remain faithful to the syllable structure of the source word but still satisfy the cross-linguistic preference for syllables with a consonantal onset is to geminate the coda consonant - at least in languages that have the singleton-geminate contrast in their phonemic repertoire. We postulate the constraints and rankings in (15) to account for this aspect of the Taviano loanword adaptation.

(15) IDENT-FINAL-CODA: penalize an output in which a word-final coda consonant in the source word is not matched by a coda consonant in the loanword adaptation

ONSET: penalize a syllable without a consonantal onset

*GEMinATE: penalize a geminate consonant

IDENT-FinAL-CODA, OnSET »*GeminAte

\begin{tabular}{|l||l|l|l|}
\hline /Ú.pim/ & IDENT-FINAL-CODA & ONSET & $*$ GEMINATE \\
\hline \hline > Ú.pim.mi & & $*$ & $*$ \\
\hline Ú.pi.mi & $* !$ & $*$ & \\
\hline Ú.pim.i & & $* * !$ & \\
\hline
\end{tabular}


A final factor differentiates Taviano from Tuscan Italian with respect to the adaptation of word-final consonants. Taviano resorts to copy-vowel epenthesis while Tuscan inserts the default vowel [e].

(16) St. Stap

$\begin{array}{lll}\text { St. Italian } & \text { Tuscan Italian } & \text { Taviano } \\ \text { lápis } & \text { lápisse } & \text { lápissi } \\ \text { gás } & \text { gásse } & \text { gássa }\end{array}$

The proposed OT analysis of this aspect of the loanword grammar is seen in (17). Following Stanton \& Zukoff (2018) we assume that copy vowel epenthesis entails a syntagmatic correspondence relation between the inserted vowel and its mate.

(17) $* \mathrm{~V}_{\mathrm{i}} \mathrm{C}_{\mathrm{o}} \mathrm{V}_{\mathrm{i}}$ : penalize a correspondence relation between the vowels of successive syllables

DEP-F's: penalize the insertion of a feature root node

\begin{tabular}{|c|c|c|c|c|c|c|c|}
\hline /gas/ & *C\# & $* \mathrm{~V}_{\mathrm{I}} \mathrm{C}_{\mathrm{O}} \mathrm{V}_{\mathrm{I}}$ & DEP-F'S & /gas/ & *C\# & DEP-F'S & $* \mathrm{~V}_{\mathrm{I}} \mathrm{C}_{\mathrm{O}} \mathrm{V}_{\mathrm{I}}$ \\
\hline gássa & & $* !$ & & $>$ gássa & & & $*$ \\
\hline$>$ gásse & & & $*$ & gásse & & $* !$ & \\
\hline gás & $* !$ & & & gás & *! & & \\
\hline
\end{tabular}

With these rankings in place we return to the anomalous stress of the Taviano loanwords. To account for the antepenultimate stress of Úpimmi and the absence of penultimate stress, the output-output faithfulness constraint for stress must outrank Weight-to-Stress. In combination with undominated Culminativity that bars more than a single stress per word, the stress of the loan is borrowed along with its segmental structure and syllable shape.

(18) IDENT-STRESS-OO: penalize a loanword that fails to preserve the stressed syllable of the source word

Culminativity, IDENT-Stress-OO » Weight-TO-Stress

\begin{tabular}{|l||l|l|l|}
\hline /Ú.pim/ & CULMINATIVITY & IDENT-STRESS-OO & WEIGHT-TO-STRESS \\
\hline \hline > Ú.pim.mi & & & $*$ \\
\hline U.pím.mi & & $* !$ & \\
\hline Ú.pím.mi & $* !$ & & \\
\hline
\end{tabular}

As shown by the adaptation of ánanas 'pineapple' as ánanassa, stress may fall outside the three-syllable window at the right edge of the word in the Taviano loanword adaptation. This will follow if IDENT-STRESS-OO dominates *EXTENDEDLAPSE-RT: 
(19) Ident-Stress-OO »*EXtended-LAPSE-Rt, Weight-TO-StRess

\begin{tabular}{|l||l|l|l|}
\hline /ánanas/ & IDENT-STRESS-OO & $*$ EXTENDED-LAPSE-RT & WEIGHT-TO-STRESS \\
\hline \hline > ánanassa & & $*$ & $*$ \\
\hline ananássa & $* !$ & & \\
\hline
\end{tabular}

According to Bafile (2003) Florentine loanwords can preserve the stress of the source word in contravention of the weight-to-stress requirement; but they still must shift their stress to respect the three-syllable window restriction (20). For this variety of Italian, IDENT-STRESS-OO falls between *EXTENDED-LAPSE-RT and WEIGHT-TO-STRESS in the constraint ranking. The Florentine examples in (20) show the spirantization of certain voiceless stops (gorgia toscana).

(20)

$\begin{array}{lll}\text { St. Italian } & \text { Florentine } & \text { Taviano } \\ \text { ánanas } & \text { ananásse } & \text { ?ánanassa } \\ \text { fílobus } & \text { filobússe } & \text { ??fílubbussu } \\ \text { áutobus } & \text { aӨobússe } & \text { ??áutubbussu } \\ \text { tícket } & \text { tíhette } & \text { tíkette } \\ \text { lápis } & \text { lápisse } & \text { lápissi } \\ \text { cógnac } & \text { kónjakke } & \text { kónjakka }\end{array}$

With the analysis of the basic prosodic structure of Taviano in place, we return to the discussion of the vocative.

\section{Vocatives and truncated vocatives}

Vocatives occur in two forms in Taviano: a full form identical to the base name and a truncated form. As near as we can tell, both types occur in the same range of contexts without major differences in meaning or pragmatic force. The main difference between the two is that the use of the truncated form normally implicates the speaker's familiarity with the addressee and is typically used in more informal settings. The data in (21) sample a range of contexts where both freely occur: (a) calling someone out of sight, (b) calling someone within sight of the speaker to attract the addressee's attention, (c) repeating the addressee's name to maintain their attention, and to express pleasure (d) or displeasure (e). The Taviano forms are paralleled by the Standard Italian ones in the second half of (21).

(21) Taviano

a. Mikéle/Miké, addú stái?

where be. $2 \mathrm{sG}$

'Michael, where are you?'

b. Ah Mikéle/Miké, addú sta+ bbai?

where PROG go.2SG

'Oh, Michael, where are you going?' 
c. Sénti, Mikéle/Miké, sta kósa nunn e+ possíbbile. hear.IMP this thing NEG is possible

'Listen, Michael, that is not possible.'

d. Gwárda, Mikéle/Miké, tt `’ e+bbéddu!

look.IMP

how is beautiful

'Look, Michael, how beautiful!'

e. Mikéle/Miké, $\mathrm{tt} f \mathrm{i}$ sta+ fátfi?

What PROG do.2sG

'Michael, what are you doing!'

St. Italian

a. Michele/Michè, dove sei?

b. Ah, Michele/Michè, dove vai?

c. Senti, Michele/Michè, questo è impossible.

d. Guarda, Michele/Michè, che bello!

e. Michele/Michè, cosa fai?

\subsection{Survey of data and generalizations}

The data in (22) illustrate the range of truncated forms for given names of different sizes and loci of the stressed syllable in Taviano. As mentioned above, the descriptive generalization noted by Alber (2009), Alber \& Arndt-Lappe (2013) and Vanrell \& Cabré (2011), based in part on an earlier study by Kuen (1932), is that the truncated form is identical to the base form up to the stressed vowel. Post-tonic material is deleted. Since the accented syllable is restricted to fall within a three-syllable window at the right edge of the word in Italian and the amount of pretonic material may range from zero to two or more syllables, the truncate has no fixed size. This factor makes it of particular interest in that there is no prosodic template to which the truncate is mapping-in contradistinction to hypocoristic formation, which as seen above, targets the bimoraic foot (with a single recursion as another option). Another difference from hypocoristics is that the vocative truncate is not associated with segmental markedness reductions and remains largely faithful to the base.

(22) vocatives in Taviano

\begin{tabular}{|l|l|l|l|l|}
\hline \multicolumn{2}{|l|}{ penultimate stress (piano) } & & \multicolumn{2}{l|}{ antepenultimate stress (sdrucciole) } \\
\hline base & truncate & & base & truncate \\
\hline Lúka & Lú & T ésare & Tfé \\
\hline Robbértu & Robbé & Kalóddzeru & Kaló \\
\hline Samuéle & Samué & Kósimu & Kó \\
\hline Filoména & Filomé & Kristóforu & Kristó \\
\hline Addoloráta & Addolorá & & \\
\hline
\end{tabular}




\subsection{Additional properties}

Below in (23) are more examples of vocative truncations in Taviano illustrating a number of restrictions on the output. As mentioned above, word-final consonants are largely barred in the dialect. As observed by Alber (2009) for Italian and Cabré \& Vanrell (2016) for Sardinian, this factor governs the output of the vocative truncation and leads to the deletion of coda consonants from the stressed syllable of the base. These codas include /s/, homorganic nasals, liquids, as well as the first half of a geminate. Taviano thus employs two different strategies to avoid word-final consonants: copy-vowel epenthesis in the case of loanwords and truncation in the case of the vocative.

(23) more vocatives in Taviano

\begin{tabular}{|l|l|l|l|l|l|l|}
\hline St. Italian & Taviano & & St. Italian & Taviano & \\
\hline & base & truncate & & & base & truncate \\
\hline Augústa & Augústa & Augú & & Robérto & Robbértu & Robbé \\
\hline Ernésto & Ernéstu & Erné & Riccárdo & Rikkárdu & Rikká \\
\hline Evarísto & Evarístu & Evarí & Gílda & Dzílda & Dzí \\
\hline Olímpo & Olímpu & Olí & Adélmo & Adélmu & Adé \\
\hline Alfónso & Alfóntsu & Alfó & Catáldo & Katáldu & Katá \\
\hline Fránco & Fránku & Frá & Ariánna & Arjánna & Arjá \\
\hline Lisándro & Lisándru & Lisá & Giuséppe & Dzuséppe & Dzusé \\
\hline Lorénzo & Loréntsu & Loré & Rócco & Rókku & Ró \\
\hline Márco & Márku & Má & & Agatélla & Akatédda & Akaté \\
\hline
\end{tabular}

There are, however, some additional restrictions on the Taviano truncate that cannot be traced to the background grammar. For example, while a falling sonority diphthong may terminate a word (cf. jéu váu ddái e+ pói stáu kkwái 'I go there and then stay here'), its high vocoid is clipped from the vocative truncate (24). Although there are many examples for the /au/ diphthong, it is difficult to test whether the same factor holds for /ai/ since this diphthong is rare word internally in the dialect. On the other hand, the rising sonority diphthong /je/ is faithfully preserved in the truncate. Its back vowel counterpart /wo/ is quite rare in Taviano. In Standard Italian /wo/ derives from Latin/Proto-Romance / $\breve{o} /$, which has the reflex /o/ in Salentino: cf. Latin bŏnus, Standard Italian buono, Salentino bónu. 


\begin{tabular}{|l|l|l|}
\hline St. Italian & Taviano base & truncated vocative \\
\hline Páolo & Páulu & Pá \\
\hline Máuro & Máuru & Má \\
\hline Cláudio & Kláudju & Klá \\
\hline Diégo & Djégu & Djé \\
\hline Daniéle & Danjéli & Danjé \\
\hline Gabriéle & Gabbrjéli & Gabbrjé \\
\hline Piéro & Pjéru & Pjé \\
\hline
\end{tabular}

These data suggest that the vocative aligns its right edge with the nucleus of the stressed syllable - the sonority peak. If this factor is built into the constraint that defines the right edge of the truncated vocative, the absence of coda consonants seen in (23) would not have to be attributed to the surrounding grammar but instead to a distinctive property of the vocative itself. It predicts that the same penchant for final vowels could be found in a language that otherwise licenses coda consonants. ${ }^{3}$

Some support for this interpretation comes from another restriction on the Taviano vocative: as seen in (25) truncates consisting of a single stressed vowel of the base are judged as ill-formed. Furthermore, alternatives that attempt to beef up the truncate with an augment (/Ándzelu/ > *Áte), or an onset (/Ándzelu/ > *Tá) or coda consonant (/Ándzelu/ $>* A t$ ), are judged no better. On the other hand, vowel-initial bases with noninitial stress truncate easily (cf. Arjánna $>$ Arjá) as do initial-stressed bases with a consonantal onset (cf. Márku> Má). Cabré \& Vanrell (2016) report a similar restriction against the V́ ... $>* V$ mapping in Sardinian. Taviano speakers judge truncations to a high vowel, while still unacceptable, as not as bad as truncation to a nonhigh vowel-especially /a/ and /e/. It is conceivable that the high vowels have the tinge of a nonvocalic onset that would ameliorate the speakers' judgments. A further phonetic study is needed to corroborate this point. The contrast between /Ándzelu/ $>* \dot{A}$ but Márku $>$ Má suggests that an organic onset consonant can contribute to weight in the absence of a coda consonant as a type of 'last resort' and is reminiscent of some native Australian languages such as Aranda (Davis 1988) where initial onsetless syllables are skipped in the stress calculation: [kútungùla] 'ceremonial assistant' but [utnádawàra] place name.

3. A case in point might be the Romanian dialects of Maramureş exemplified in (2d) above, although Maiden (2006) does not contain all the data needed to fully substantiate this claim. Parrott (2010) reports that penultimate stressed personal names and kinship terms in Russian can truncate their final vowel in the vocative; coda consonants are retained in some cases (Nikita $>$ Nikit, Petrúška > Petrúšk, rebjáta > rebját 'guys') but can be deleted in others (máma 'mommy'> ma, pápa 'daddy' > $p a, b a ́ b a$ 'granny' $>b a$ ). Yardav (1996) describes a greater variety of such truncations for Russian; but all seem to end in a consonant or consonant cluster with no further simplification: Serjóža > Serjóš, Marinočka > Marínočk, Mustafá > Mustáf, Mimí > Mim (indeclinable). 


\begin{tabular}{|l|l|l|l|l|l|l|}
\hline St. Italian & Taviano base & truncate & St. Italian & Taviano base & truncate \\
\hline Ágata & Ákata & $*$ Á & Éva & Éva & $*$ É \\
\hline Áldo & Áldu & $* A ́$ & & Éttore & Éttore & $*$ É \\
\hline Ángelo & Ándzelu & $*$ Á & Íva & Íva & ?'́ \\
\hline Ánna & Ánna & $* A ́$ & Ítalo & Ítalu & ?'́ \\
\hline Áda & Áda & $*$ Á & Ísa & Ísa & ?'́ \\
\hline Élena & Élena & $* E ́$ & Ída & Ída & ?'́ \\
\hline Énzo & Éntsu & $*$ É & Úgo & Úgu & ?'́ \\
\hline
\end{tabular}

In these cases of (25) a phonological minimality requirement against a Prosodic Word consisting of a single vowel short-circuits a morphological operation and leads to the null output as the optimal candidate. (See Cabré \& Kenstowicz 1995 for a similar phenomenon in Catalan).

\section{Prior analyses-1 (Alber 2009)}

Alber (2009) proposes a detailed analysis of the Southern Italian vocative truncation, which we review here. It is presented in the context of a comparison with the two hypocoristic truncations. The analysis is cast within the OT framework as an Output-Output relation between the base form and the truncate. The hypocoristic constructions differ from the truncated vocative by targeting a disyllabic trochaic foot - the same structure assumed for the more general stress placement in Italian. So-called 'size-restrictor constraints' of FoOT-BINARITY, PARSE-SYLLABLE, and ALLFT-LEFT as well as the foot-form constraint TROCHEE impose a disyllabic, initial stress structure on the truncate. Which particular phonemes compose the truncate is controlled by anchoring constraints that specify the left and right edges of the hypocoristic with respect to the base. Alber argues that these constraints belong to the alignment family on the grounds that in Slavic languages like Russian the left edge of a truncate can pass over an onsetless syllable to target a more optimal CV structure, as in Antonjéta > Tónja. Alber's analysis of the three truncation structures in Italian is treated as a function of the ranking of three Anchor constraints: ANCHOR-LEFT, ANCHOR-Right, and ANCHOR-STRESS. For left-edge faithful nicknames such as Francésca > Fránce, ANCHOR-LEFT predominates and chooses Fránce over Césca, as seen in the tableau below (26).

ANCHOR-LEFT » ANCHOR-STRESS, ANCHOR-Right

\begin{tabular}{|l||l|l|l|}
\hline Francésca & ANCHOR-LEFT & ANCHOR-STRESS & ANCHOR-RIGHT \\
\hline \hline$>$ Fránce & & $*$ & sca \\
\hline Césca & Fran! & & \\
\hline
\end{tabular}


Right-edge faithful structures with penultimate stress such as Amerígo $>$ Rígo are ambiguous between whether right-edge alignment or stressed syllable alignment is the decisive factor.

AnCHOR-STRESS, ANCHOR-Right » ANCHOR-LEFT

\begin{tabular}{|l||l:l|l|}
\hline Amerígo & ANCHOR-STRESS & ANCHOR-RIGHT & ANCHOR-LEFT \\
\hline (Rígo) & & & Ame \\
\hline (Áme) & $*$ & rigo & \\
\hline
\end{tabular}

But antepenultimately accented formations like Doménico > Méni and Cristóforo $>$ Stófo show that anchoring to the stressed syllable must dominate anchoring to the right edge. Alber treats this factor as faithfulness between the stress of the base and the stress of the truncate.

(28) Anchor Stress » Anchor-Right, AnCHOR-Left

\begin{tabular}{|l||l|l|l|}
\hline Doménico & ANCHOR-STRESS & ANCHOR-RIGHT & ANCHOR-LEFT \\
\hline \hline$>$ (Méni) & & co & Do \\
\hline (Níco) & $* !$ & & Dome \\
\hline
\end{tabular}

In the majority of cases the size restrictor constraints and CONTIGUITY predominate to shift the right edge of the truncate leftward past the final syllable and thus choose Méni over Ménico and Méco.

(29) SRC, Contiguity » Align-Right

\begin{tabular}{|l||l:l|l|}
\hline Doménico & SRC & Contiguity & Align-Right \\
\hline \hline$>$ (Méni) & & & co \\
\hline (Ménico) & $* !$ & & \\
\hline (Méco) & & ni! & \\
\hline
\end{tabular}

Alber cites formations like Doménico > Ménico and Cristóforo > Stóforo from Thornton (1996) to argue that ANCHOR-RigHT also plays a role in defining the templates for truncation and hence must figure into the typology even though it lacks the psycholinguistic backing of ANCHOR-LEFT and ANCHOR-STRESS, which are known to play a significant role in lexical access (Cutler 2012).

ANCHOR-Right, CONTIGUITY » SRC

\begin{tabular}{|l||l|l|l|}
\hline Doménico & ANCHOR-RIGHT & CONTIGUITY & SRC \\
\hline \hline$>$ (Ménico) & & & $*$ \\
\hline (Méni) & co! & & \\
\hline
\end{tabular}


CONTIGUITY is high ranked since the truncate normally forms a single block of segments excised from the base though for markedness reasons violations may occur sporadically, as in Beatrice $>$ Bice.

\begin{tabular}{|l||l|l|}
\multicolumn{2}{|c}{$*$ Complex OnSET $\gg$ Contiguity } \\
\hline /Beatríce/ & $*$ CompleX-Onset & Contiguity \\
\hline \hline$>$ Bíce & & eatr \\
\hline Tríce & $* !$ & \\
\hline
\end{tabular}

With this background in place we turn to Alber's (2009) analysis of the truncated vocatives. The basic intuition lying behind the analysis is that their variable and unrestricted size can be fitted within the overall typology of truncations by calling on the two major constraints ANCHOR-LEFT and ANCHOR-STRESS that define the hypocoristics and letting them dominate the size-restrictor constraints. This move produces an 'atemplatic' output which is said to not be enforced by any metrical (rhythmic) considerations. The truncation of Salvatóre $>$ Salvató is shown in tableau (32) below.

ANCHOR-LEFT, ANCHOR-STRESS » SRC

\begin{tabular}{|l||l|l|l|}
\hline /Salvatóre/ & ANCHOR-LEFT & ANCHOR-STRESS & SRC \\
\hline \hline$>$ Salvató & & & $*$ \\
\hline Sálva & & $* !$ & \\
\hline Tóre & Sálva! & & \\
\hline
\end{tabular}

Since for Alber the preservation of the stressed syllable of the base in the truncate is treated as a faithfulness effect rather than as a product of alignment, another constraint must be called on to implement the truncation of the post-tonic material. Otherwise, lower-ranked ANCHOR-RIGHT will stretch the truncate to align with the base at its back end, generating the fully faithful candidate as the output (33).

\begin{tabular}{|l||l:l|l|l|}
\hline /Salvatóre/ & ANCHOR-LEFT & ANCHOR-STRESS & ANCHOR-RIGHT & SRC \\
\hline \hline Salvató & & & re! & $*$ \\
\hline Sálva & & $* !$ & & \\
\hline Tóre & Sálva! & & & \\
\hline$>$ Salvatóre & & & & \\
\hline
\end{tabular}

To solve this problem Alber appeals to a member of the COINCIDE family of constraints from Zoll (1996): CoINCIDE-SYLL-1. This constraint requires all of the 
syllables to align with the left edge of the prosodic word. Since they cannot pile on top of one another, deletion is the optimal repair and eliminates all but the first syllable from the output.

\begin{tabular}{|l||l|l|}
\hline /Salvatóre/ & CoINCIDE-SYLL-1 & ALIGN-RIGHT \\
\hline \hline$>$ Salvató & vató & $*$ \\
\hline Salvatóre & vatóre! & \\
\hline
\end{tabular}

Alber utilizes the COINCIDE-SYLL-1 constraint to generate monosyllabic hypocoristics such as those in (35) below which, while not otherwise mentioned in the literature, were collected from Northern Italian students at Verona and independently confirmed for us by a speaker from Trento.

$\begin{array}{ll}\text { (35) Francésca } & \text { Frá } \\ \text { Cristína } & \text { Crí } \\ \text { Luísa } & \text { Lú } \\ \text { Stefánia } & \text { Sté }\end{array}$

The tableau below shows this treatment of these structures in Alber's analysis.

\begin{tabular}{|c||c|c|c|c|c|}
\hline Base: Francésca & COINCIDE- $\sigma_{1}$ & FTBIN & ANCHOR-L & ANCHOR-S & ANCHOR-R \\
\hline \hline a. (Frá) & & $*$ & & $*$ & ncesca \\
\hline b. (Frán.ce) & ce! & & & $*$ & sca \\
\hline c. (Cé) & & $*$ & Fran! & & sca \\
\hline d. (Scá) & & $*$ & France! & $*$ & \\
\hline
\end{tabular}

Without knowing more about the background grammar of such speakers, it is difficult to judge the plausibility of this analysis - in particular that CoINCIDESYLL-1 is the factor responsible for shaving off the right edge of the base in (34). For example, it is unclear how to account for the loss of the offglide in Páulu $>P a ́$ since the alternative Páu satisfies faithfulness for stress and COINCIDE-SYLL-1. The substratal Northern Italian dialects are well known for unstressed vowel deletion (apocope and syncope). It is conceivable that the derivation of Frá might proceed from intermediate Frán.ce rather than being directly generated from the full name. If so, then the independent motivation for the COINCIDE-SYLL-1 constraint is called into question and hence its role in the vocative truncation as well. 
6. Prior-Analyses-2 (Vanrell \& Cabré 2011; Cabré \& Vanrell 2016; Cabré et al. 2019)

Based on corpora collected from Sardinian, Eastern Catalan, and some Southern Italian speakers, Vanrell \& Cabré (2011), Cabré \& Vanrell (2016), Cabré et al. (2019) treat the vocative truncation as a byproduct of constraints aligning the truncate with nuclear pitch accents that are associated with the vocative formations. Here we focus on their discussion of Sardinian (Cabre et al. 2019), which is the most worked out analysis. Their data were collected from six native speakers who were asked to imagine two scenarios for using a vocative. In the first ('direct call'), the speaker calls an unseen addressee assumed to be close by (e.g. in another room in a house). In the second scenario ('insistent call'), the speaker, having received no response to the direct call, repeats the call assuming the addressee to be located more distantly but still within earshot of the speaker. Similarly to our data with Taviano (recall 21 above), the specific intonational tune can be applied to both truncated as well as non-truncated, full-form vocatives. For Sardinian it consists of a $\mathrm{L}+\mathrm{H}^{*}$ rise mapped to the first syllable and an $\mathrm{L}^{*}$ assigned to the stressed syllable followed by a L\% boundary tone ${ }^{4}$. The intonation contour is illustrated by the truncated form of Eleonóre $>$ Eleonó with a rise on the first syllable and a low target on the stressed syllable at the right edge of the truncate (37). The two medial syllables appear to be associated with the $\mathrm{H}$.

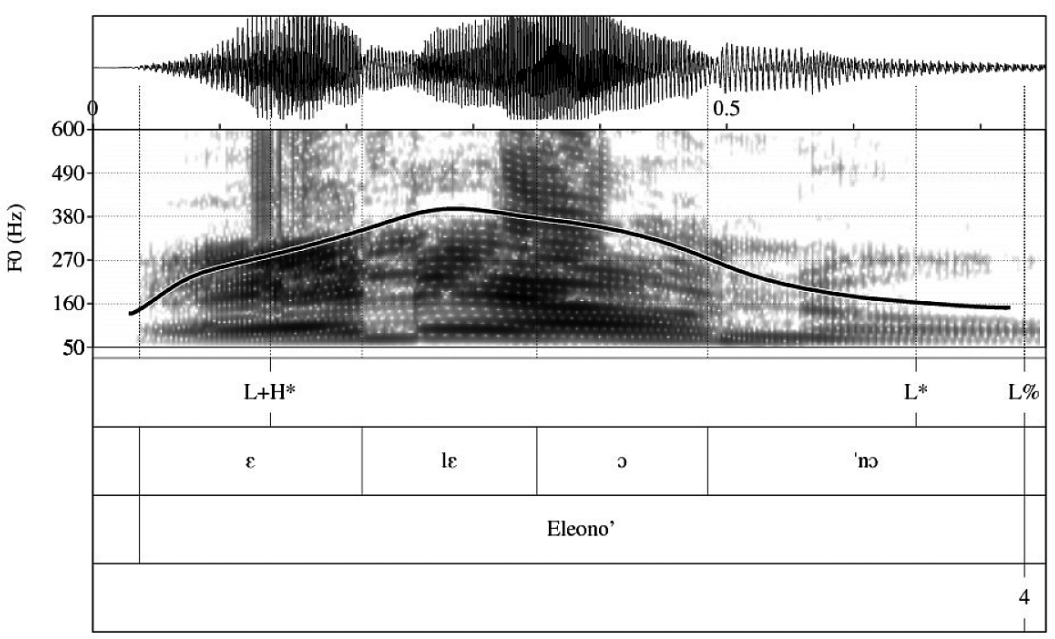

As far as we can tell, Cabré et al. (2019) propose a two-step derivation of the vocatives. In the first step, the two pitch accents associated with the vocative

4. The $\mathrm{L}+\mathrm{H}^{*}$ notation seems to imply a stress accent on the initial syllable. As near as we can tell, a $\%$ LH boundary tone would also be consistent with the Sardinian data. 
are mapped to the full-form of the base: "Whether truncation happens or not, the intonational pattern applied to the base is the same" (p. 35). In a second step, the truncate is derived from the full form vocative by a categorical alignment constraint that requires the syllable with the $\mathrm{L}^{*}$ pitch accent to coincide with the right edge of the prosodic word. Thus, in this analysis, the truncation is in effect stipulated as a product of alignment and both are compiled into a single constraint that transforms the full form vocative into the truncated form. This approach contrasts with Alber's more granulated interpretation in which alignment to the stressed syllable is factored out into a more general stress faithfulness phenomenon that is found outside of the truncation per se and which we saw plays a significant role in Taviano loanword adaptation and more generally in output-output faithfulness in derivational morphology.

\section{Prior-Analyses-3 (D’Alessandro \& van Oostendorp 2016)}

It is precisely this point that D'Alessandro \& van Oostendorp (2016) focus on in their discussion of vocative truncation. They motivate the truncation with the assumption that the nuclear tone falling on the stressed syllable of the vocative originates as a right-edge boundary tone in the construction. Truncation is interpreted as a strategy to minimize the distance between the right edge of the containing structure and the boundary tone so that they coincide. But given that the vocative construction can apparently occur with the same intonation contour in both the full form as well as the truncated form, there is no necessary connection between truncation and the vocative. At best, under this analysis, truncation is an optimizing TETU-like effect that improves the fit between the F0 contour and its segmental "text". Future research should conduct an instrumental study of the full form and the truncated vocatives to establish in fact whether or not their pitch contours are distinct and if so whether the truncated form can reasonably be derived from a right-edge boundary tone. See Jeong (2018) for a recent study along these lines that differentiates two types of rising declaratives in English.

\section{Summary of Phonological Characteristics of the Vocative}

While more data are surely welcome, it is possible to discern some general trends in the typology of vocatives that distinguish them from hypocoristics. First, hypocoristics are templatic while vocatives are not. Second, hypocoristics may be associated with truncation at the left or the right edge of the base. All cases of vocative truncation that we are aware of truncate material at the right edge and remain faithful to the left edge. Third, vocative truncation seems to be motivated by the desire to align the right edge of the truncate with prominence. The prominence can take a number of forms: the sonority peak of the stressed syllable (Taviano), a stressed or stressless syllable with a consonantal coda (Romanian, Russian), a pitch accent (Sardinian), or a lengthened vowel (Yupik: Miyaoka 2012: 859). Fourth, while hypocoristics are often accompanied by segmental and syllabic markedness reductions (TETU), vocatives seem more faithful to the base. In sum, the phonol- 
ogy of vocatives mimics the general character of phonology (and more broadly of grammar) as a whole. There are general trends with possible external motivation; but they are embedded in a system of conflicting forces that can be resolved in various ways. More research is needed to better circumscribe the overall typology.

\section{Morphological and Grammatical Properties of the Taviano Vocative}

In addition to phonological constraints such as the minimality requirements discussed in 4.2, Salentino's vocative truncation also obeys morphosyntactic constraints pertaining to the nature and size of possible bases. In the canonical case, the truncation base is a single word, such as a name, a nickname, a conventional or professional title, or any other form of address, including plurals (38).

(38) a. Brigánti $\rightarrow$ Brigá

b. Pinnatédda $\rightarrow$ Pinjaté

c. professóre $\rightarrow$ professó

d. vannuntféddu/-ddi $\rightarrow$ vannuntfé surname

nickname, lit. 'small pot'

'professor'

'little boy/boys' [diminutive of vannóne 'boy']

A branching structure made up of two words is also relatively acceptable (39), albeit with somewhat degraded outcomes in cases of adjectival or possessive modification $(40) .^{5}$

(39) a. sinnóra Terésa $\rightarrow$ sinnora Teré

'Mrs. Teresa'

b. mé $\int \mathrm{u}$ Marju $\rightarrow \operatorname{me} \iint u$ Má

'master craftsman [title] Mario'

c. Márku Rittsu $\rightarrow$ Marku Rí

‘Marco Rizzo’ [name and surname]

(40) a
a. kummáre nóf a grandmother our.F.SG
b. béddu
beautiful.M.SG boy
$\rightarrow$ ?*kummare no

By contrast, more complex NP structures are all decidedly unacceptable as inputs for vocative truncation, despite making for fine vocative nominals if left untruncated (41).

5. Similar examples of minimally complex vocative truncates have been noted elsewhere in the literature on vocative truncation in Italo-Romance. Rohlfs (vol. 1: 448-9) reports bella fée $<$ mmina $>$ 'beautiful woman' for Abruzzese, tsi mmo<nako $>$ 'uncle monk' for Ischia's dialect, and Jaku $\mathrm{Fa}<$ rre $>$ (name + surname) for Sardinian. Comparable examples involving compound names and surnames have recently been discussed by D'Alessandro \& Van Oostendorp (2016). 


$\begin{array}{lll}\text { (41) a. Márku Ríttsu de Tajánu } & \rightarrow \text { *Marku Rittsu de Tajá } \\ \text { NAME SURNAME from Taviano } & \\ \text { b. beddu de nonna } & \rightarrow \text { *bedqu de nó } \\ \text { darling of grandmother } & \\ \text { 'Granny's darling' } \\ \begin{array}{l}\text { c. tíe ka pórti li kkjáli } \\ \text { 2sG that wear.2sG the glasses }\end{array} \\ \text { 'You who are wearing glasses' }\end{array}$

Importantly, in those limited cases where truncation can target a branching nominal phrase, truncation never applies distributively to each component word of that phrase, but always to the right edge of the phrase as a whole (42). This pattern thus differs starkly, for example, from the one displayed by vocative exponence in Latin and other Indo-European languages, where vocative "case" morphology shows up (under most circumstances, obligatorily) on every possible component word within the vocative nominal (43).

(42) a. sinnóra Terésa $\rightarrow$ sinnora Teré/*sinnó Teré/*sinnó Teresa 'Mrs Teresa'

b. mé $\int u$ Márju $\rightarrow$ me $\iint u$ Má/*me Má/*me Márju 'master craftsman [title] Mario'

(43) Latin (Plautus, 3rd-2nd century BC)

uālē bene, ocul-e mī

fare.IMP well, eye-VOC my.VOC

'farewell, my eye!' [The nominative would have been oculus meus]

Although exempt from concord phenomena such as that in (43), Taviano's vocative truncation does behave like canonical inflectional morphology in that it may be fed by derivational morphology; but it can never feed derivation. In general, vocative truncation appears to be a morphological "dead end," never providing an input for further affixation, as illustrated by the impossibility of appending diminutive suffixes like -útffu and -inu to any vocative truncate. The problem with such diminutivized truncates cannot straightforwardly be reduced to the hiatus between the truncate-final vowel and the úlí of the diminutive, given that such hiatuses are allowed elsewhere in the language (e.g. faúnnu 'sultriness', kjaútu 'coffin').

(44) a. Dunátu $\rightarrow$ Duná $\nrightarrow$ *Dunaútffu

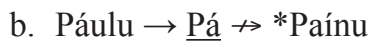

The ungrammatical examples in (44) should be contrasted with the grammatical ones in (45), where diminutive morphology applies to the base rather than to the truncate. 
(45) a. Dunátu $\rightarrow$ Dunatútffu $\rightarrow$ Dunatú

b. Páulu $\rightarrow$ Paulínu $\rightarrow \underline{\text { Paulí }}$

The fact that truncation can apply equally successfully to a non-diminutive or a diminutive base (compare the underlined forms in (44) and (45)) also shows that there is no privileged base that the process preferentially applies to. This point is further illustrated in (46) with examples involving hypochoristics and diminutives of hypochoristics.
(46) a. Dzuséppe $\rightarrow$ dzusé
(plain base)
b. Péppe $\rightarrow$ Pé
(hypochoristic)
c. Péppe $\rightarrow$ Peppínu $\rightarrow$ Peppí
(diminutive of hypochoristic)

Finally, it is also worth noting the existence of syntacto-semantic constraints on Taviano vocativization, which apply to truncated and non-truncated vocatives alike. In particular, it turns out to be impossible for the vocative nominal to be preceded by any articles, despite the fact that they are generally obligatory on definite nominals, including proper names. For example, the relevant allomorphs of the singular definite article - (l) $u$ and $l$ ' for the masculine, (l) $a$ and $l$ ' for the feminine - cannot be omitted in argumental uses of proper names such as those exemplified in (47). But they must be omitted in the corresponding vocatives (48).

(47) a. $\{U / * \varnothing\}$ Kósimu è+ Jutu kkasa.

DEF Cosimo is gone home

'Cosimo has gone home.'

b. Addzu kuntatu ku+ *(la) María have.1SG talked with DEF Maria 'I have talked with Maria.'

(48) a. (*A) Marí(a), si+ Juta kkasa?

DEF Maria be. 2SG gone home

'Maria, are you back home?'

b. (*U) Kó(simu), tokka+ kuntamu

DEF Cosimo is.necessary talk.1PL

'Cosimo, we need to talk.'

As already mentioned, this restriction holds of vocatives irrespective of truncation, and instantiates a cross-linguistically frequent pattern. Similar bans on articles in vocatives have been reported for several other languages that admit or require articles before proper names. Cases in point include Seri (isolate, Mexico; Marlett 2008), Austrian German (Göksel \& Pochträger 2013: 89), Modern Greek, 
and Venetian dialects of Italo-Romance (Hill 2014: 66). ${ }^{6}$ A natural explanation for this pattern revolves around the idea that "[i]n the Vocative Phrase, definite articles do not check definiteness, since the addressee semantics is inherently definite and referential" (Hill 2014: 62). This definiteness requirement is presumably imposed - via syntactic selection or semantic definedness conditions - by the functional structure that hosts the vocative nominal. In this respect, we follow the literature (Moro 2003; Stavrou 2009, and much subsequent work) in positing a vocativededicated functional head $\mathrm{Voc}^{0}$, which we take to host the vocative noun phrase in its specifier, and to be a part of the highest functional field at the left periphery of the clause, encoding information about discourse participants and utterance context.

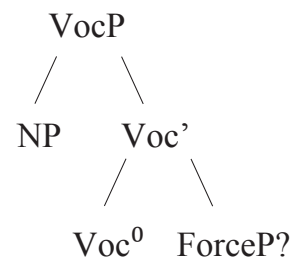

Other heads in the same region of the clausal structure have been invoked in accounts of phenomena such as speaker- and addressee-oriented adverbs, allocutive agreement, indexical shift, and a lot more. Unlike some of these phenomena, however, the possibility of expressing a vocative seems to be cross-linguistically restricted to matrix-clause environments only, which we take to show that VocP can never be projected in the periphery of an embedded clause, no matter how structurally big.

(50) a. Sinnore, da-mme a salute

Lord give-IMP-1SG.CLIT the health

'O my Lord, give me good health.'

b. O $\int \mathrm{i}$ preku (*Sinnore) $\mathrm{ku}^{+}$(*Sinnore) me daje a salute Today pray.1sG Lord COMP Lord 1SG.CLIT gives the health 'Today I'll pray that He give me good health.'

c. O $\int \mathrm{i}$ nne diku (*Sinnore) ka (*Sinnore) tokka+ me Today 3.DAT say.1SG Lord COMP Lord must 1sG.CLIT daje a salute gives the health 'Today I will tell Him that He has to give me good health.'

6. Similarly but not identically, vocative nominals in Zulu do not need any "augment" (Halpert 2012: 136; Janson 2013: 230-231) — a prefix analyzed as an "intrinsic case licensor" by Halpert (2012). 


\section{Summary and conclusion}

This paper has documented and analyzed the formation of truncated vocatives in the Taviano dialect of Salentino Italian. Our findings align in general terms with those reported for Sardinian, Algherese Catalan, and certain Romanian dialects. The truncate has no fixed size in contrast to hypocoristics, which target a disyllabic trochaic foot. The vocative truncate is faithful to the left edge of the base while its right edge aligns with the base's stressed syllable. The paper discussed whether or not additional restrictions on the truncate can be attributed to the background grammar or must be stipulated as properties of this particular construction. Our investigation of Taviano uncovered novel findings on the shape of word-final syllables, which are enforced differently between native words and loanwords. Subtle differences with regard to the locus of stress in loanword adaptation among Taviano, Florentine, and Standard Italian can be expressed as different rankings in an OT grammar. The paper concluded with a discussion of certain morphological and syntactic restrictions on the Taviano vocatives and their parallels in other languages. More cross-linguistic research is needed to better circumscribe the range of variation of this until recently largely overlooked structure.

\section{References}

Alber, Birgit. 2010. An exploration of truncation in Italian. Rutgers Working Papers in Linguistics 3: 1-30.

Alber, Birgit \& Arndt-Lappe, Sabine. 2012. Templatic and subtractive truncation. In Trommer, Jochen (ed.). The Morphology and Phonology of Exponence, 289-325. Oxford: Oxford University Press.

Bafile, Laura. 2003. Le consonanti finali nel fiorentino e nel napoletano. Rivista Italiana di Dialettologia 27: 149-178.

Burani, Cristina, Paizi, Despina \& Sulpizio, Simone. 2014. Stress assignment in reading Italian: friendship outweighs dominance. Memory \& Cognition 42: 662-675.

Boyd-Bowman, Peter. 1955. Cómo obra la fonética infantile en la formación de los hipocorísticos. Nueva Revista de Filología Hispánica 9: 337-366.

Cabré, Teresa \& Kenstowicz, Michael. 1995. Prosodic trapping in Catalan. Linguistic Inquiry 26: 694-705.

Cabré, Teresa \& Vanrell, Maria del Mar. 2011. Accent i entonació en els vocatius de l'alguerès. In La toponomàstica de les illes del Mediterrani occidental (XXXV Col·loqui de la Societat d'Onomàstica l'Alguer, maig del 2008), València-l'Alguer: Editorial Denes, S.L., 331-341.

Cabré, Teresa \& Vanrell, Maria del Mar. 2016. Truncation in Sardinian: prosodic vs. intonational templates. Unpublished ms.

Cabré, Teresa; Torres-Tamarit, Francesc \& Vanrell, Maria del Mar. 2019. Truncation in Sardinian. Unpublished ms.

Calabrese, Andrea. 1984. Metaphony in Salentino. Rivista di Grammatica Generativa 9-10: 1-140.

Chierchia, Gennaro. 1986. Length, syllabification, and the phonological cycle in Italian. Journal of Italian Linguistics 8: 5-33. 
Cutler, Anne. 2012. Native Listening: Language Experience and the Recognition of Spoken Words. Cambridge, MA: MIT Press.

D'Alessandro, Roberta \& van Oostendorp, Marc. 2016. When imperfections are perfect: prosody, phi-features and deixis in Central and Southern Italian vocatives. In Carrilho, Erenestina, Fieis, Alexandra, Lobo, Maria \& Pereira, Sandra. Romance Languages and Linguistic Theory 10: Selected Papers from 'Going Romance' 28 Lisbon, 61-82. Amsterdam \& Philadelphia: John Benjamins.

Davis, Stuart. 1988. Syllable onsets as a factor in stress rules. Phonology 5: 1-19.

Göksel, Aslı \& Pochträger, Markus. 2016. The vocative and its kin: marking function through prosody. In Sonnenhauser, Barbara \& Hannah, Aziz (eds.). Vocative! Addressing between System and Performance, 87-107. Berlin: De Gruyter Mouton.

Felíu, Elena. 2001. Output constraints on two Spanish word-creation processes. Linguistics 39(5): 871-891.

Halpert, Claire. 2012. Argument Licensing and Agreement in Zulu. Ph.D. dissertation. Cambridge (MA): Massachusetts Institute of Technology.

Hill, Virginia. 2014. Vocatives: How Syntax Meets with Pragmatics. Leiden: Brill.

Ito, Junko. 1990. Prosodic minimality in Japanese. Chicago Linguistic Society 26(2): 213-239.

Ito, Junko, Kubozono, Haruo \& Mester, Armin. To appear. A prosodic account of consonant gemination in Japanese loanwords. In Kubozono, Haruo (ed.). The Phonetics and Phonology of Geminate Consonants. Oxford: Oxford University Press.

Janson, Tore. 2016. Vocative and the grammar of calls. In Sonnenhauser, Barbara \& Hannah, Aziz (eds.). Vocative! Addressing between System and Performance, 219234. Berlin: De Gruyter Mouton.

Jeong, Sunwoo. 2018. Intonation and sentence type conventions: two types of rising declaratives. To appear in Journal of Semantics.

Kenstowicz, Michael. 2005. The phonetics and phonology of Korean loanword adaptation. In S-J. Rhee (ed.). Proceedings of the First European Conference on Korean Linguistics, 17-32. Seoul: Hankook Publishing Co.

Kurisu, Kazutaka. 2001. The Phonology of Morpheme Realization. Ph.D. dissertation, University of Californa Santa Cruz.

Kiparsky, Paul. 1984. On the lexical phonology of Icelandic. In Elert, Claes-Christian, Johansson, Irene \& Strangert, Eva (eds.). Nordic Prosody III, 135-164. University of Umea.

Kuen, Heinrich. 1932. El dialecto de Alguer y su posición en la historia de la lengua catalana. Anuari de l'Oficina Romànica de Lingüistica i Literatura V: 121-177.

Maiden, Martin. 2006. On Romanian imperatives. Philologica Jassyensia, An II, Nr. 1: 47-59.

McCarthy, John \& Prince, Alan. 1986. Prosodic Morphology. Ms. University of Massachusetts, Amherst and Brandeis University, Waltham, Mass. [Annotated version 1996, issued as Technical Report no. 32, Rutgers Center for Cognitive Science.]

Marlett, Stephen. 2008. The form and use of names in Seri. International Journal of American Linguistics 74: 47-82.

Martinez-Paricio, Violeta \& Torres-Tamarit, Francesc. To appear. Trisyllabic hypocoristics in Spanish and layered feet. Natural Language \& Linguistic Theory. 
Miyaoka, Osahito. 2012. A Grammar of Central Alaskan Yupik. Berlin: De Gruyter Mouton.

Moro, Andrea. 2003. Notes on vocative case: a case study in clause structure. In Quer, Josep \& Schroten, Jan (eds.). Romance Languages and Linguistic Theory 2001, 247-261. Amsterdam: John Benjamins.

Oresnik, Janez. 1972. On the epenthesis rule in Modern Icelandic. Arkiv for Nordisk Filologi 87: 1-32.

Parrott, Lillian. 2010. Vocatives and other direct address forms: a contrastive study. In Grønn, A. \& Marijanovic, I. (eds.). Russian in Contrast, Oslo Studies in Language 2(1): 211-229.

Passino, Diana. 2008. Aspects of Consonantal Lengthening in Italian: A Case Study of Gemination of Word-final Consonants in the Adaptation of Loanwords. HALCCSD. Revised version of University of Padua Ph.D. dissertation, 2005.

Piñeros, Carlos Eduardo. 2000. Prosodic and segmental unmarkedness in Spanish truncation. Linguistics 38: 63-98.

Prieto, Pilar. 1992. Truncation processes in Spanish. Studies in the Linguistic Sciences 22(1): 143-158.

Repetti, Lori. 1993. The integration of foreign loans in the phonology of Italian. Italica 70(2): 182-196.

Repetti, Lori. 2012. Consonant-final loanwords and epenthetic vowels in Italian. Catalan Journal of Linguistics 11: 167-188.

Rohlfs, Gerhard (1966-1969). Grammatica Storica della Lingua Italiana e dei Suoi Dialetti. 3 vols. Turin: Einaudi.

Shinohara, Shigeko. 1997. Analyse phonologique de l'adaptation japonaise de mots étrangers. Ph.D. dissertation. University of Sorbonne-Nouvelle Paris III.

Stanton, Juliet \& Sam Zukoff. 2018. Prosodic identity in copy epenthesis: evidence for a correspondence-based approach. Natural Language \& Linguistic Theory 36(2): 637-684.

Stavrou, Melita. 2009. Vocative! Ms. Aristotle University of Thessaloniki.

Thornton, Anna. 1996. On some phenomena of prosodic morphology in Italian: accorciamenti, hypocoristics and prosodic delimitation. Probus 8: 81-112.

Vanrell, Maria del Mar \& Cabré, Teresa. 2011. Troncamento e intonazione dei vocativi in Italia centromeridionale. In Gili-Fivela, B., Stella, A., Garappa, L., \& Grimaldi, M. (eds.). Contesto comunicativo e variabilità nella produzione e percezione della lingua: Atti del $7^{\circ}$ convegno AISV. Roma: Bulzoni.

Yardoff, Michael. 1996. Modern Russian vocatives: a case of subtractive morphology. Journal of Slavic Linguistics 4(1): 133-153. 


\section{Appendix}

\begin{tabular}{|l|l|}
\hline bárra & 'iron bar' \\
\hline bárra & 'bar, café' \\
\hline Bríndisi & placename \\
\hline karémme & Puppets symbolizing Lent \\
\hline kastími & 'curse' 2 sg. \\
\hline Fíatta & brandname \\
\hline sorélle & 'sisters' \\
\hline mámma & 'mama' \\
\hline Mikéle & personal name \\
\hline otélle & 'hotel' \\
\hline piáta & 'take.imp.2sG 3FEM.SG for yourself' \\
\hline piatele & 'take.imp.2sG those.FEM \\
\hline ridímmi & 'tell me again' \\
\hline ridíssi & 'say again' (priterite 1.SG) \\
\hline rifátta & 'made again' (participle FEM) \\
\hline ste\#fSéme & 'these idiots' \\
\hline tándemme & 'tandem' (two-seat bicycle) \\
\hline tennissi & 'tennis' \\
\hline trámma & 'tram' \\
\hline últimi & 'final' pl. \\
\hline úpimmi & brand name \\
\hline vénime & 'come IMP.2sG-1 sG.DAT' \\
\hline
\end{tabular}

